\title{
ARSITEKTUR CINA PADA KLENTENG JIN DE YUAN DI KAWASAN PECINAN JAKARTA SEBAGAI SUATU PERWUJUDAN AKULTURASI KEBUDAYAAN
}

\author{
Polniwati Salim \\ Jurusan Desain Interior, Fakultas Komunikasi dan Multimedia, Bina Nusantara University, \\ Jln.K.H. Syahdan No.9, Jakarta Barat 11480 \\ Polnilim@binus.ac.id
}

\begin{abstract}
Cultural acculturation can be seen from various aspects, where the fusion of two cultural elements will not remove the could go to Indonesia and was applied to the temples in Indonesia, but still did not leave the cultural elements of Indonesia. Temple Jin De Yuan was one of the many temples in Jakarta, especially in the area of Chinatown, an area in terms of population, form of shelter, social order and the atmosphere of the environment had historically rooted characteristic of cultured Chinese people which was very thick with the architecture Chinese. Article presents how the application of Chinese architecture as a manifestation of Chinese culture and acculturation Indonesia in the temple Jin De Yuan can increase the cultural treasury of Indonesia. The research applied qualitative method and also library research.
\end{abstract}

Keywords: cultural acculturation, Chinatown, Chinese architecture

\begin{abstract}
ABSTRAK
Akulturasi kebudayaan dapat dilihat dari berbagai aspek, yaitu merupakan perpaduan dua unsur kebudayaan yang tidak akan menghilangkan unsur asli dari kedua kebudayaan tersebut. Arsitektur Cina dengan khas budaya Cina dapat masuk ke Indonesia dan diaplikasikan pada klenteng di Indonesia, namun tetap tidak meninggalkan unsur budaya Indonesia. Klenteng Jin De Yuan merupakan salah satu dari sekian banyak klenteng di DKI Jakarta, khususnya di kawasan Pecinan, suatu kawasan yang dari segi penduduk, bentuk hunian, tatanan sosia,l serta suasana lingkungan memiliki ciri khas berakar secara historis dari masyarakat berkebudayaan Cina yang sangat kental dengan arsitektur Cina. Artikel menjelaskan bagaimana pengaplikasian arsitektur Cina sebagai perwujudan akulturasi kebudayaan Cina dan Indonesia pada klenteng Jin De Yuan sehingga mampu menambah perbendaharaan kebudayaan Indonesia.Penelitian menggunakan metode kualittaif dan studi pustaka.
\end{abstract}

Kata kunci: akulturasi kebudayaan, kawasan pecinan, arsitektur Cina 


\section{PENDAHULUAN}

Akulturasi adalah suatu proses sosial yang timbul manakala suatu kelompok manusia dengan kebudayaan tertentu dihadapkan dengan unsur dari suatu kebudayaan asing. Kebudayaan asing itu lambat laun diterima dan diolah ke dalam kebudayaannya sendiri tanpa menyebabkan hilangnya unsur kebudayaan kelompok itu sendiri. akulturasi juga merupakan suatu perpaduan antara kebudayaan yang berbeda yang berlangsung secara damai dan serasi,. Sebuah akulturasi kebudayaan dapat terjadi di banyak aspek, antara lain pada seni bangunan, seni lukis, seni sastra, kalender, kepercayaan dan filsafat, pemerintahan, dan lainnya.

Salah satu contoh akulturasi adalah pada klenteng Jin De Yuan yang merupakan klenteng tertua di kawasan kota tua Jakarta, yang berdiri di kawasan pecinan, dengan penduduk berbudaya Indonesia. Arsitektur cina mendominasi klenteng ini, tapi tetap tidak meninggalkan unsur budaya Indonesia. Diharapkan dengan pemahaman lebih mendalam mengenai arsitektur cina di klenteng ini yang mencerminkan akulturasi budaya, membuka mata kita mengenai kayanya budaya yang dapat dikawinkan dengan budaya Negara Indonesia.

Awalnya kelenteng ini disebut Kwan Im Teng (Guan Yin Ting), karena diperuntukkan sebagai kelenteng untuk menghormati Dewi Kwan Im (Guan Yin), sesuai dengan arti harafiahnya yang berarti Paviliun Guan Yin. Seperti catatan yang dikutip Adolf Heuken dalam Historical Sites of Jakarta (1989) dari Claudine Salmon dan Denys Lombard dalam Les Chinois de Jakarta: temples et vie collectives (1977), dinyatakan bahwa sekitar tahun 1650 Letnan Tionghoa Guo Xun Guan (Kwee Hoen) mendirikan sebuah kelenteng untuk menghormati Guan Yin (Kwan Im) di Glodok. Konon dari kata Kwan Im Teng inilah kemudian timbul istilah kelenteng yang berarti "kuil Tionghoa”.

Kelenteng ini mengalami perusakan dan pembakaran ketika terjadi Pembantaian Angke pada tahun 1740 dan hanya sebuah meja sembahyang (yang dibuat tahun 1724) yang tersisa dari peristiwa pembakaran tersebut. Lima belas tahun setelah itu, seorang Kapten Tionghoa memugar kembali kelenteng ini, kemudian mengganti namanya dengan sebutan Kim Tek Ie (Jin de Yuan) atau Kelenteng Kebajikan Emas. Kelenteng Jin de Yuan merupakan kelenteng umum, artinya tidak secara khusus diperuntukkan sebagai tempat pemujaan salah satu agama/aliran saja, tetapi digunakan untuk pemujaan berbagai agama, seperti Tao, Khonghucu, dan Buddha.

Kelenteng utama terletak di halaman ke dua. Di kelenteng ini terdapat sebuah pembakar uang kertas persembahan yang disebut Jin Lu, dibuat di Kwangtung pada tahun 1812, sekarang Jin Lu tertua ini diletakan di halaman belakang. Ujung-ujung atap gedung induk melengkung ke atas dalam gaya yang disebut "Gaya Ekor Walet”. Dahulu untuk arsitektur bangunan yang menggunakan ujung bumbungan seperti ini, bersama sepasang singa batu, hanya boleh dipakai untuk menghiasi bangunan kelenteng dan gedung-gedung para pemuka masyarakat Tionghoa (berpangkat Mayor, Kapten, dan Letnan), sedangkan orang biasa dan hartawan hanya boleh membangun rumah atau toko dengan bentuk atap yang disebut "Gaya Pelana”. 


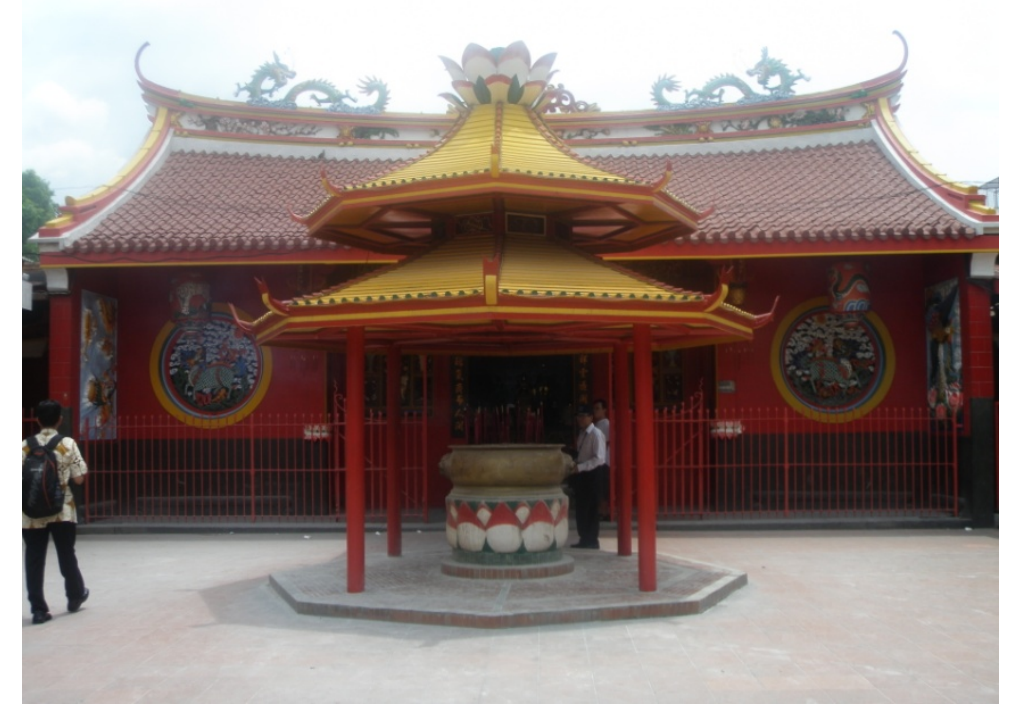

Gambar 1 Tampak depan Kelenteng Jin de Yuan (Dok. Polni, 2011)

Pola peletakkan ruang pada bangunan keagamaan terdiri atas 2 konsep, yaitu : ruang yang dianggap suci dan ruang yang tidak suci. Pada kelenteng Jin de Yuan terdiri dari : ruang depan, Impluvium (courtyard), ruang samping, dan ruang suci utama. Area depan meliputi bagian serambi (teras) dan ruang bagian dalam. Untuk area tengah, pada Impluvium ketinggian lantai dibuat lebih rendah, sedangkan lantai di ruang suci utama bagian depan, samping, dan belakang lebih tinggi posisinya. Pada area belakang, yaitu ruang suci utama, dibagi menjadi 3 ruangan untuk pemujaan dewa-dewi. Ruangan yang di bagian tengah lebih besar, diperuntukkan sebagai penempatan altar dewi utama.

Pada ruang suci utama bagian depan, tepat depan pintu masuk terdapat meja altar dan diletakkan sebuah patung dewa Wei Tuo. Wei Tuo merupakan dewa penjaga kelenteng dengan sikap membelakangi pintu masuk (karena menghadap ke arah dalam kelenteng). Patung yang ada di kelenteng Jin de Yuan diposisikan sedang memegang pedang dengan kedua tangan di dada. Pada posisi sebaliknya, yang menghadap pintu masuk diletakkan patung dewa Mi-le-fo (dewa obat) yang diletakkan bertolak-belakang dengan patung dewa Wei Tuo. Di atas ambang pintu bagian dalam terdapat sebuah kotak berisi 3 patung San Yuan (kaisar 3 dunia) yang merupakan dewa Taoist. Di sudut ruang sebelah timur dekat pintu masuk terdapat area penjualan keperluan upacara. Di sudut ruang sebelah barat diletakkan lemari obat-obatan.

Setelah melewati altar Wei Tuo dan Impluvium, ada ruang suci utama yang di paling belakang dengan lantai paling tinggi, yaitu untuk dewi Kwan Im. Di sana terdapat sebuah bejana kuningan dan meja panjang tempat buku-buku kitab suci diletakkan. Ruang patung dewa dikelilingi kaca dan diberi tirai merah, ditempatkan pula lampu kristal bundar di tengah ruangan. Di bagian atas tirai terdapat kain sutera bersulam huruf Tiongkok sebagai sumbangan seseorang umat yang telah mengalami kesuksesan. Di setiap ruang pemujaan dewa itu tersedia meja panjang untuk persembahan, dilengkapi dengan 2 pelita kehidupan yang terus menyala di sisi kiri dan kanan, 2 jambangan besar, lampu keramik bundar, serta terdapat beberapa piring berisi sajian kue dan buah-buahan.

\section{Kawasan Pecinan}

Pada perkembangan di luar Cina, banyak dikenal lingkungan China Town atau Pecinan seperti di kota-kota negara Asia, Eropa, Amerika dan Australia yang menjadi landmark kota yang menarik 
para turis mancanegara. Identitas China Town di negara-negara tersebut dengan karakteristik kegiatan yang hidup didalamnya, menjadi lingkungan bersejarah yang umumnya merupakan kumpulan/kelompok bangunan yang membentuk suatu komunitas masyarakat Cina dengan ciri/karakter bangunannya yang khas, memiliki berbagai dekorasi dan elemen-elemen serta pintu gerbang juga sebagai tempat aktvitas perdagangan (bisnis) retail seperti restoran, pertokoan, teater dan bangunan rekreasi lainnya. Kawasan Pecinan adalah kawasan yang merujuk pada suatu bagian kota yang dari segi penduduk, bentuk hunian, tatanan sosial serta suasana lingkungannya memiliki ciri khas karena pertumbuhan bagian kota tersebut berakar secara historis dari masyarakat berkebudayaan Cina.

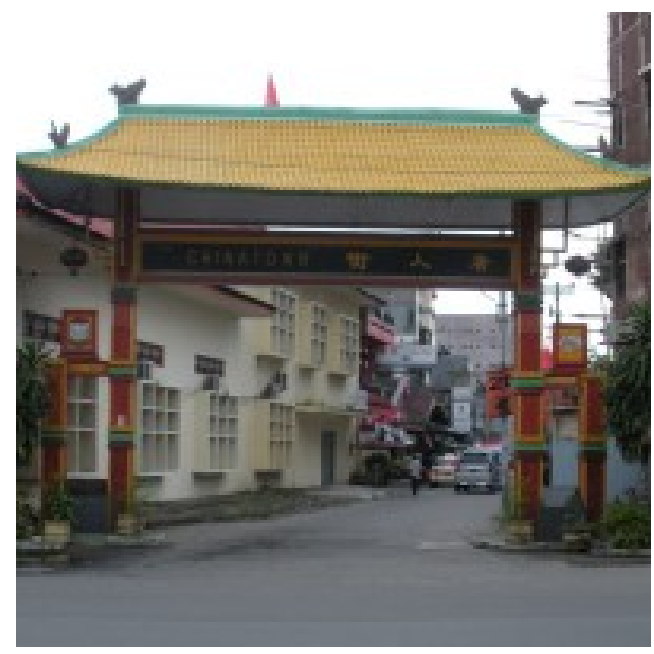

Gambar 2. Pintu Gerbang Kawasan Pecinan (China Town) (sumber : http://www.visitmakassar.net/chinatown-makassar/)

Untuk bisa melihat arsitektur Cina di suatu kota, biasanya harus melihat di daerah Pecinannya. Namun, untuk menentukan tempat bekas daerah Pecinan pada suatu kota tidaklah mudah. Hal ini selain karena perkembangan kota yang sangat cepat, juga karena biasanya daerah Pecinan tidak terdokumentasi dengan baik. Sampai saat ini di Kawasan Pecinan masih berdiri bangunan-bangunan dengan aplikasi budaya Cina, yaitu dengan bentuk atap lengkung yang dalam arsitektur Cina disebut atap pelana sejajar gavel. Bentuk atap yang ditemui di Kawasan Pecinan hampir sama dengan bentuk atap yang ditemukan di daerah Cina selatan. Kebanyakan imigran-imigran Cina yang datang ke Indonesia merupakan imigran yang berasal dari propinsi-propinsi di Cina bagian selatan seperti Fukien, Chekian, Kiang Si, dan Kwang Tung, karena propinsi tersebut mempunyai tingkat kemakmuran yang rendah dan panen hasil pertanian mereka sering gagal karena sering terkena bencana alam. Selain itu, tembok yang tebal, plafon yang tinggi, lantai marmer, dan beranda depan dan belakang yang luas juga menandakan adanya gaya Eropa dalam bangunan yang terdapat di Kawasan Pecinan.

\section{Kelenteng di Indonesia}

Istilah kelenteng merujuk pada suatu suara yang terdengar di bangunan suci tersebut saat sedang menyelenggarakan upacara sembahyang. Seringkali terdengar bunyi kelenting, yang pada akhirnya masyarakat menamakan bangunan ini sebagai kelenteng. Dalam penyebutan bahasa Mandarin, dilafalkan dengan penambahan istilah "bio" atau "miao". Kelenteng ini diperuntukkan sebagai tempat beribadah kepada Tuhan, nabi, dan arwah leluhur dari Konfusianisme, Taoisme, dan Buddhisme. 
Pada tahun 1965, istilah kelenteng diganti penyebutannya menjadi vihara (dibaca : wihara), karena situasi politik saat itu di mana pemerintah Indonesia melarang segala hal yang berhubungan dengan Cina yang diasumsikan berkaitan dengan PKI. Nama dari kelenteng-kelenteng di Jakarta dikaitkan dengan pemujaan dewa-dewi di dalamnya atau nama jalan tempat berdirinya bangunan itu. Kelenteng-kelenteng di Jakarta, antara lain : Vihara Dewi Samudera (Tian Hou Gong), Kelenteng Dewi Welas Asih, Da Bo Gong Miao (Toa Pe Kong), Lu Ban Gong / Kelenteng Lu Ban (perlindungan bagi tukang kayu), Kelenteng Lie Tie Guai, Vihara Padi Lapa (kelenteng persekutuan pedagang minyak dan beras), dan salah satu kelenteng tua yang ternama dan bersejarah di kawasan Pecinan Jakarta adalah Kelenteng Kim Tek Ie (Jin de Yuan).

\section{Budaya Cina dalam Arsitektur}

Secara kosmologis, tradisi arsitektur Cina melambangkan semesta-langit dalam bentuk-bentuk bulat dan dunia-Bumi dalam bentuk kubus. Susunan arsitektur berbatas dinding biasanya ditemui dalam penataan geometris yang ketat, persegi panjang, maupun bujur sangkar, ditata berdasarkan arah mata angin. Arah utara-selatan menjadi acuan utama, mungkin karena secara klimatologis, angin utara yang dingin menjadi kontras terhadap angin selatan. Ruang ditata berlapis-lapis dalam suatu seri pola grid yang tegas baik bentukan ruang luar (courtyards) maupun dalam susunan ruang dalam.

Arsitektur Cina dahulu dibangun tidak dengan bahan-bahan permanen. Susunan geometris, ritual-ritual, dan nilai hadir lebih utama dari bangunan yang dianggap fana. Semua proporsi dan aturan tergantung pada sistem standart dimensi kayu dan standard pembagiannya. Dengan demikian keseluruhan bangunan Cina dirancang dalam modul standard dan moduler dari variabel ukuran yang absolut proporsi yang benar melindungi dan mempertahankan hubungan harmoni bagaimanapun besarnya struktur.

Arsitektur khas oriental yang berasal dari dataran Cina, memang memiliki akar budaya yang sangat tua dan dilestarikan dengan baik selama beribu-ribu tahun. Masyarakat keturunan Tionghoa bila berada di daerah baru juga selalu membawa budaya mereka yang mengakar kuat. Sama seperti kebudayaan Eropa yang memiliki ornamen atau hiasan khas arsitektur mereka, arsitektur khas oriental juga memiliki kekhasan bentuk-bentuk ornamentasi, seperti hiasan pada dinding, pintu dan jendela yang didasarkan pada mitos dan kepercayaan bangsa Tionghoa. Ornamen yang ada beragam dari ornamen geometris, motif tanaman dan binatang.

Dari segi desain interior, gaya oriental ditandai dengan penggunaan material kayu, kertas pelapis dinding dan warna yang dominan merah, cokelat tua atau emas. Gaya ukiran dalam interior khas oriental biasanya berbentuk ukiran seperti naga dan singa. Bunga lotus pun kerap digunakan sebagai motif ukiran ataupun lukisan. Atap khas Cina yang berwarna mencolok seperti merah, biru, dan kuning, atau penggunaan patung naga digunakan sebagai wujud kepercayaan. Gawangan atau kongliong juga sering digunakan sebagai penyambung antar-ruang tanpa menggunakan pintu yang berbentuk bulat seperti bulan purnama.

Ciri arsitektur lainnya seperti penggunaan Fengshui untuk arsitektur cukup memberikan banyak batasan sekaligus kreativitas dalam penataan ruang, perabot dan aksesori rumah lainnya. Penempatan letak gedung dan bangunan buatan manusia diatur seimbang dan menguntungkan dengan lingkungan fisik di sekitarnya. Fengshui tersebut diwujudkan dalam ukuran ruang, pemberian warna, dan urutan rangkaian pembangunan, semuanya dipercaya akan membawa berkah. Adapun aturan yang berlaku dengan menggunakan Fengshui, yaitu :

Konstruksi atap : Rancangan atau dekorasi pada bubungan merupakan hal penting. Bentuk yang digunakan seperti naga, burung Hong, dan binatang berkaki empat lain adalah dianggap baik untuk bubungan, yang dapat menimbulkan kebahagiaan dan keberuntungan. 
Pemberian warna tertentu : warna juga sangat penting, karena warna tertentu memiliki arti tersendiri. Umumnya digunakan warna kuning, hijau, dan biru yang melambangkan simbol kekuatan, panjang umur, dan rahmat Tuhan.

Penomoran ruangan secara tepat memegang peranan besar. Angka 1, 5, 9 diartikan baik. Sedangkan angka 4 harus dihindarkan. Lokasi bangunan Cina umumnya memiliki karakter tanah bergelombang dan terdapat banyak warna, berdekatan atau menghadap jalur air (sungai, danau yang tenang, atau laut), dan ditanami berbagai tumbuhan, terutama yang dapat bertahan terhadap cuaca. Karakter bangsa Tionghoa yang juga cukup menghargai dunia material terlihat pada penggunaan hiasan yang sangat rumit, indah, serta bernilai seni tinggi, karena menunjukkan kekayaan secara material dianggap menambah martabat bagi sebagian orang Tionghoa tradisional.

Begitu berlawanan dengan Arsitektur Barat, yang cenderung untuk berkembang pada tinggi bangunan dan kedalaman bangunan, Arsitektur Cina menekankan pada dampak visual dari jarak menyangkut bangunan tersebut. Corak penting yang lain adalah penekanan pada simetri, yang berarti suatu perasaan, pengertian, dan kehebatan ini berlaku dari istana hingga ke rumah petani. Satu pengecualian adalah dalam perancangan kebun, cenderung asimetri dan bukan simetri. Bangunan Cina dapat dibangun baik dengan warna merah maupun batu bata abu-abu, tetapi struktur kaku dari kayulah yang paling umum; karena kayu lebih mampu untuk menahan gempa bumi, tetapi peka terhadap api. Atap bangunan Cina pada umumnya dibengkokkan, ada penggolongan tegas tentang yang berbeda pada jenis nok atap, hampir sama dengan lapisan kayu tiang sejajar rancangan klasik Eropa.

Penggolongan Cina pada unsur arsitektur, meliputi: lou ( Multistory bangunan), tai ( teras), ting ( paviliun), ge (Two-Story paviliun), ta ( Pagoda Cina), xuan (beranda dengan Jendela), xie ( Paviliun atau rumah teras), dan wu (Ruang sepanjang koridor)

Pada arsitektur kelenteng secara jelas terlihat pada gaya bubungan atapnya yang seperti busur dengan ujung kiri dan kanannya mencuat ke atas, masing-masing terbelah dua. Bubungan atas (tongcid) seperti itu disebut yanbue atau ekor walet. Sepasang singa batu (cioqsar atau killin) di kirikanan memperkuat kesan sebagai bangunan persembahan. Di tempat asalnya, bangunan seperti itu punya posisi istimewa dalam masyarakat. Pada masa akhir dinasti Qing di Tiongkok (1644-1911), berlaku ketentuan, ujung bubungan atap mirip ekor walet dan sepasang singa batu hanya boleh digunakan untuk bangunan pemerintahan dan keagamaan serta kediaman pejabat pemerintah. Rakyat biasa dilarang menggunakan simbol itu. Orang kebanyakan hanya diizinkan memakai bubungan atap bergaya pelana (bepeu), juga tanpa sepasang singa batu.

\section{Ciri Arsitektur Tionghoa daerah Pecinan sampai sebelum tahun 1900}

Khol menulis dalam "Chinese Architecture in The Straits Settlements and Western Malaya”, memberikan semacam cirri arsitektur orang Tionghoa yang ada terutama di Asia Tenggara. Ciri-ciri tersebut adalah sebagai berikut:

Courtyard : Courtyard merupakan ruang terbuka pada rumah Tionghoa. Ruang terbuka ini sifatnya lebih privat, biasanya digabung dengan kebun/taman. Rumah gaya Tiongkok Utara sering terdapat courtyard yang luas dan kadang-kadang lebih dari satu, dengan suasana yang romantis. Di daerah Tiongkok Selatan tempat banyak orang Tionghoa Indonesia berasal, courtyard lebih sempit karena lebar kapling rumahnya tidak terlalu besar.

Rumah orang Tionghoa Indonesia yang ada di daerah Pecinan jarang mempunyai courtyard. Kalaupun ada, lebih berfungsi untuk memasukkan cahaya alami siang hari atau untuk ventilasi saja. Courtyard pada arsitektur Tionghoa di Indonesia biasanya diganti dengan teras yang cukup lebar. Courtyard menjadi ukuran status penghuni ditambah ornamen aristektur lain, baik dalam wujud 
inskripsi yang menunjukkan tingkat intelektualitas maupun dalam wujud simbol kosmologis yang menunjukkan status si pemilik di dalam masyarakat.

Bentuk atap: Penekanan pada bentuk atap yang khas. Di antara semua bentuk atap arsitektur Tionghoa, hanya ada beberapa yang paling banyak dipakai di Indonesia. Di antaranya jenis atap pelana dan ekor walet dengan ujung yang melengkung ke atas.
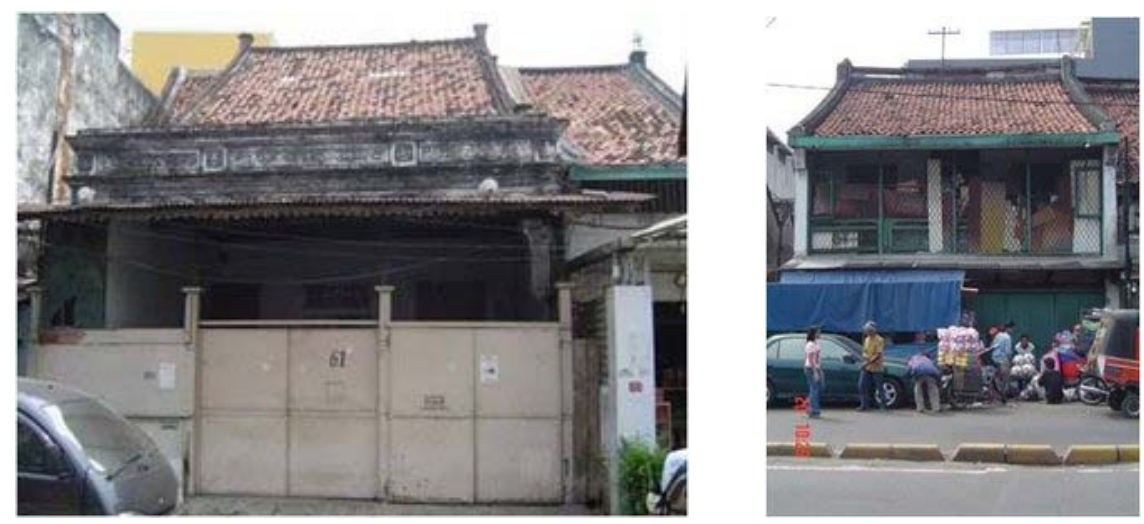

Gambar 3a dan 3bBangunan rumah dengan bentuk atap pelana

(Sumber : http://kalika19.multiply.com/journal/item/2, 2011)

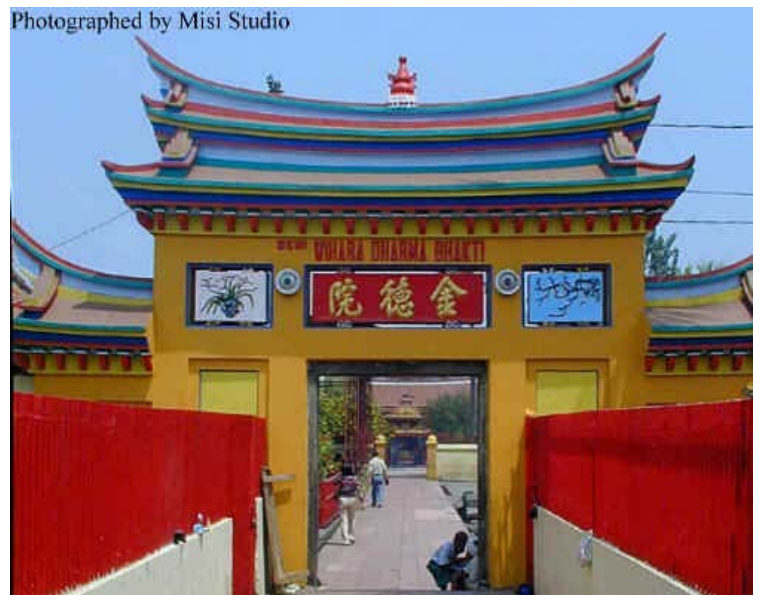

Gambar 4. Gapura utama memasuki lingkungan kelenteng dengan bentuk atap ekor wallet

(Sumber : http://jindeyuan.org/arsitektur, 2011)

Elemen struktural yang terbuka (terkadang disertai dengan ornamen ragam hias). Keahlian orang Tionghoa terhadap kerajinan ragam hias dan konstruksi kayu tidak dapat diragukan lagi. Ukirukiran serta konstruksi kayu sebagai bagian dari struktur bangunan dapat dilihat sebagai ciri khas pada bangunan Tionghoa. Detil konstruktif seperti penyangga atap (tou kung), atau pertemuan antara kolom dan balok, bahkan rangka atapnya dibuat sedemikian indah, sehingga tidak perlu ditutupi, bahkan diekspos tanpa ada finishing tertentu, sebagai bagian dari keahlian pertukangan kayu yang piawai. 


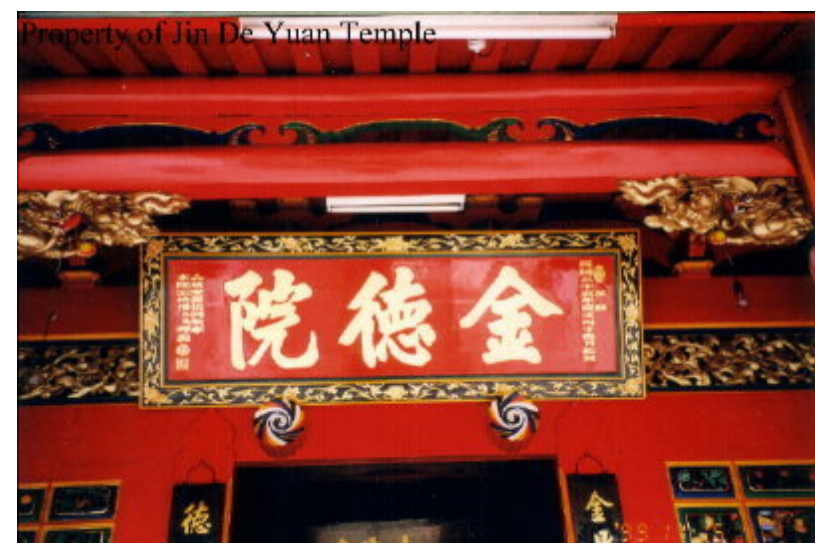

Gambar 5. Langit-langit pada pintu utama penuh dengan pola dan ukiran kayu (Sumber : http://jindeyuan.org/arsitektur, 2011)

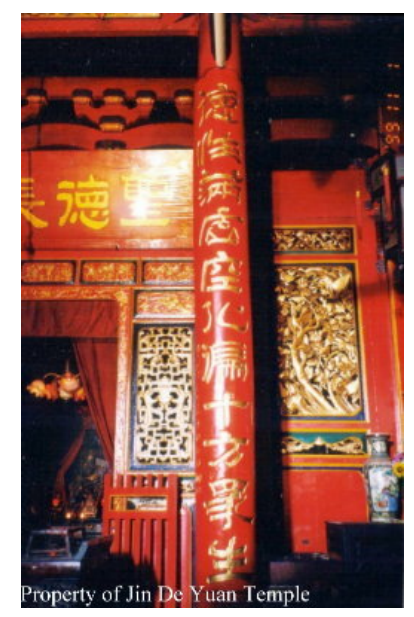

Gambar 6. Kaligrafi menghiasi pilar penyangga (Sumber : http://jindeyuan.org/arsitektur, 2011)

Penggunaan warna yang khas. Warna pada arsitektur Tionghoa mempunyai makna simbolik. Warna merah dan kuning keemasan paling dominan digunakan dalam arsitektur Tionghoa di Indonesia. Warna merah banyak dipakai di dekorasi interior, dan umumnya dipakai untuk warna pilar. Merah merupakan simbol warna api dan darah, yang dihubungkan dengan kemakmuran dan keberuntungan. Merah juga adalah simbol kebajikan, kebenaran dan ketulusan. Warna merah juga dihubungkan dengan arah, yaitu arah Selatan, serta sesuatu yang positif. 


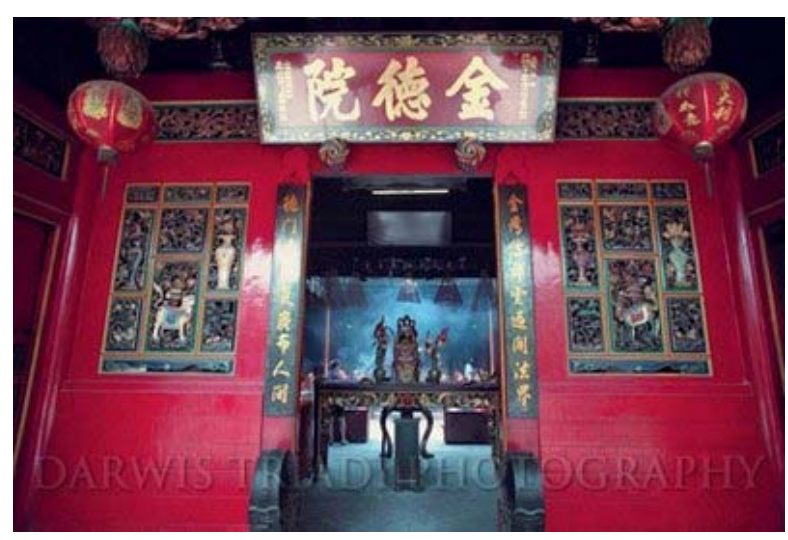

Gambar 7. Pintu masuk berwarna dominan merah (Sumber : http://darwistriadi.blogspot.com, 2011)

\section{PENUTUP}

Kelenteng Jin de Yuan merupakan salah satu kelenteng tertua di Jakarta yang dari tahun 1650 hingga saat ini masih berdiri dengan kokoh. Dari bentuk bangunan klenteng dapat terlihat arsitektur bergaya Cina dengan ciri khas bagian atap jenis pelana dan ekor wallet dengan ujung melengkung keatas, demikian pula dengan pemilihan warna yang membawa unsur fengsui sesuai dengan kebudayaan Cina, demikian pula dengan pembagian area dalam klenteng yang mengikuti ciri khas arsitektur Cina. Namun demikian tidak mentah-mentah menjadikan klenteng Jin De Yuan ini total bergaya Cina pleh karena pemilihan bentuk arstetkturnya. Diharapkan pada masa pemugaran ataupun renovasi mendatang, nilai kebudayaan Cina masih tetap bisa diperlihatkan sebagai wujud akulturasi dua kebudayaan yang berbeda.

\section{DAFTAR PUSTAKA}

Asti Kleinsteuber \& Syafri Maharadjo. (2010).Kelenteng-kelenteng Kuno di Indonesia. Jakarta: PT. Gramedia Printing.

David G. Khol.(1984). Chinese Architecture in The Straits Settlements and Western Malaya: Temples Kongsis and Houses, Kuala Lumpur: Heineman Asia.

N. Widayati \& D. Sumintardja.(2003). Jurnal Kajian Teknologi : Permukiman Cina di Jakarta Barat (Gagasan Awal Mengenai Evaluasi SK Gubernur No. 475/1993). Surabaya: Institut Teknologi Sepuluh November.

R.P. Lilananda.(1998). Penelitian: Inventarisasi Karya Arsitektur Cina di Kawasan Pecinan Surabaya. Surabaya: Universitas Kristen Petra. 